\title{
Andrew Theodossi
}

In this Obituary (BMJ 2013;347:f6263, doi:10.1136/bmj.f6263) the date listed for Andrew Theodossi's death should have read 26 April 2012, not "2013" as was published.

Cite this as: BMJ 2014;348:g1201

๑ BMJ Publishing Group Ltd 2014 